\title{
The Sister Joseph's Nodule Historical Perspective Presentation of a Clinical (Own) Case Discussion and Review of the Literature
}

\author{
Hunis $\mathrm{M}^{1}$, Hunis $\mathrm{AP}^{1^{*}}$ \\ ${ }^{1}$ School of Medicine, University of Buenos Aires (UBA), Argentina
}

Corresponding Author: Adrian P. Hunis, MD

Address: Board Certified in Medical Oncology, Assistant Professor of Internal Medicine, School of Medicine, University of Buenos Aires (UBA), Head Professor of Oncology, Maimonides University, Argentina; E-mail: ahunis@fmed.uba.ar Received date: 03 September 2020; Accepted date: 09 October 2020; Published date: 20 October 2020

Citation: Hunis M, Hunis AP. The Sister Joseph's Nodule Historical Perspective Presentation of a Clinical (Own) Case Discussion and Review of the Literature. J Health Care and Research. 2020 Oct 20;1(3):166-71.

Copyright (c) 2020 Hunis M, Hunis AP. This is an open-access article distributed under the Creative Commons Attribution License, which permits unrestricted use, distribution, and reproduction in any medium, provided the original work is properly cited.

\section{Abstract}

In this article, we present a patient in our series with a rare presentation of her disease, metastasis in the navel, due to disseminated ovarian cancer. This clinical situation is named after an American nun. Sister María José. We describe the history of the religious, the illness of our patient and we discuss medical and pathophysiological aspects as a contribution to medical casuistry.

\section{Keywords}

Umbilical Nodule, Metastasis, FNAC

\section{Introduction}

The Sister Joseph's nodule is a deep subcutis mass in the umbilical area that is associated with metastases from intra-abdominal cancer, usually of ovarian, gastric, pancreatic, or colorectal origin. It is the only case of an eponymous named after a nurse. Its use is rare on the European continent and more frequent in North America.

\section{Historical Perspective:}

When we speak of Sister Mary Joseph (Fig-1), we are referring to Julia Dempsey, who was born in 1856 in Salamanca, New York State, according to some, and outside Rochester, Minnesota, according to others. She was the daughter of Patrick and Mary (Sullivan) Dempsey, immigrants from Ireland. Three of her daughters were nuns of the Saint Francis order. Julia entered the congregation in 1878 and was ordained as a Sister Mary Joseph at the age of 22. Her organizational and managerial skills soon stood out, causing her to rise early in the order's hierarchy. She became director of the Congregation's missionary school in Ashland, Kentucky, in 1880 at the age of 24 . In 1889 she was transferred to the newly opened St. Mary's Hospital in Rochester at the request of Mother Alfred Moes, the founder of the order [1].

In 1883 a tornado swept through the city of Rochester. After the disaster, the Sisters of St. Francis urged the most competent surgeon and doctor in the area, William Worral Mayo (1815-1911), to establish a hospital. They contributed the necessary amount of money, which was, at the time, $\$ 2,000$. It opened on October 1, 1989, with five nurses and thirteen patients. Its first directors were the sons of W. W. Mayo, Charles Horace, and William James. During the first year, 300 surgeries were performed, reaching 600 in 1906. 
Citation: Hunis M, Hunis AP. The Sister Joseph's Nodule Historical Perspective Presentation of a Clinical (Own) Case Discussion and Review of the Literature. J Health Care and Research. 2020 Oct 20;1(3):166-71.

\section{Case Series}

Sister Maria Jose joined the staff on November 10, 1889, without knowing anything about nursing. She acquired her first knowledge and skills from Edith Graham, who had graduated from the Chicago Women's Hospital School of Nursing and would later become the wife of Charles Mayo. She was the first professional with a degree from the state of Minnesota. Within six weeks, Sister Mary Joseph was appointed chief nurse, and within a year she became William Mayo's first surgical assistant. Due to her great management skills, three years later she reached the rank of superintendent of the Hospital. She was one of those responsible for the successive expansions of the hospital; eight between 1894 and 1931 [2].

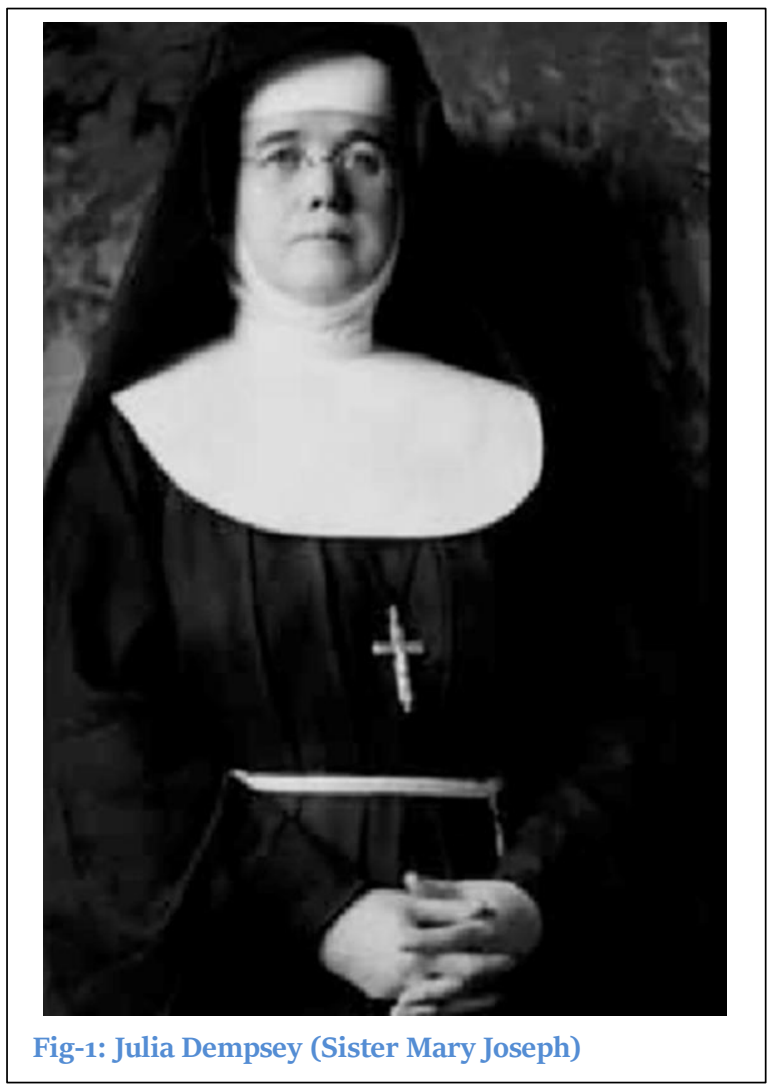

The Mayo brothers (Fig-2) preferred to work with few highly qualified and trained personnel. They soon incorporated the innovations that were emerging at the time regarding anesthesia, antisepsis and asepsis, and methods to prevent bleeding. This allowed them to perfect the interventions on the abdomen that until then they had only performed in cases of emergency. Soon patients came from all over the world as well as doctors who wanted to learn these new techniques. Sister Mary Joseph's hands were so small that they could slip into any corner of the body where
Mr.Mayo's hands could not reach. It was also normal for her to make the first incision as well as to close the surgical wound at the end of the operation [3].

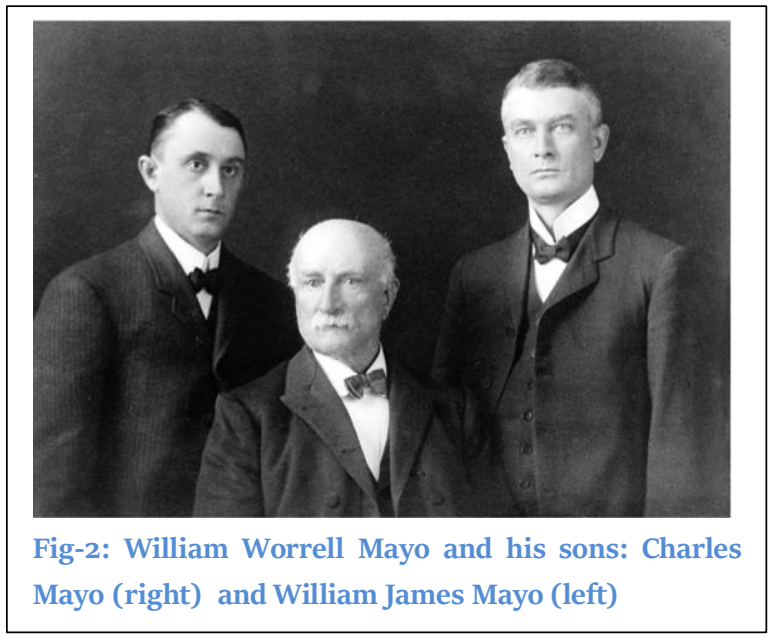

Sister Maria Joseph was the first person to call attention to the presence of a para-abdominal nodule, which was often the only sign of malignant intraabdominal cancer. This finding was recorded by William Mayo in an article he published in 1828, but he referred to this module as "pants button umbilicus". It was Hamilton Bailey in his eleventh edition of his manual entitled Physical Signs in Clinical Surgery, published in 1949, who first used the eponymous. Sometimes this is the only evidence that a malignant neoplasm exists and indicates a poor prognosis. The ease with which it can be accessed avoids the discomfort that other histopathological diagnostic methods can cause.

Like Florence Nightingale, Sister Mary Joseph was aware that nurses should receive a formal training. In November 1906, the Saint Mary's Hospital Nursing School was formally opened, and in 1915 it received accreditation from the Minnesota State Medical Committee. The two-year curriculum was extended by one more year, and the teaching structure was maintained until 1970. Sister Mary Joseph also stimulated university training among members of her order who had to work in hospitals. Thus, some were trained in dietetics, others in hospital administration, and others in nursing [4].

Sister Mary Joseph refused many honors and tributes during her lifetime. She died of 
Citation: Hunis M, Hunis AP. The Sister Joseph's Nodule Historical Perspective Presentation of a Clinical (Own) Case Discussion and Review of the Literature. J Health Care and Research. 2020 Oct 20;1(3):166-71.

\section{Case Series}

bronchopneumonia at the age of 82, on March 29, 1939. She is buried in St. Joseph's Cemetery in Rochester.

Recently the original building of Saint Mary's Hospital (Mayo Clinic, Fig-3) has been named Joseph Hospital in his honor. It so happens that a few weeks later William and Charles Mayo also died [5].

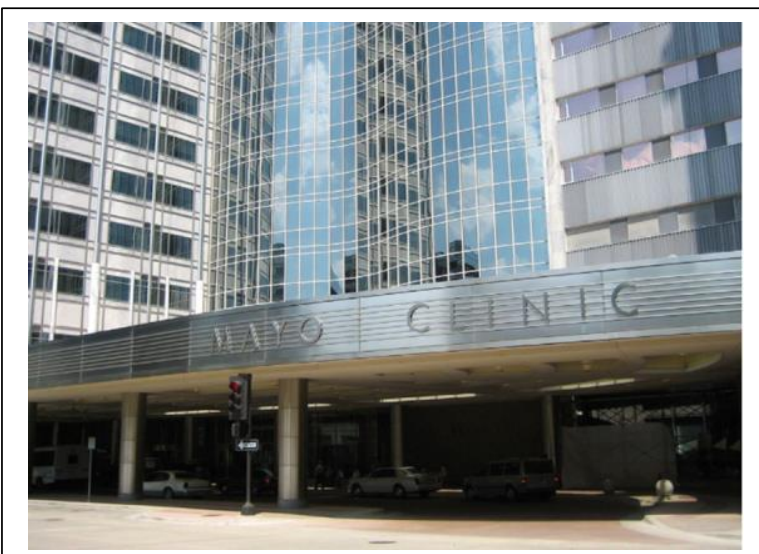

Fig-3: Mayo Clinic

\section{Clinical Case}

This is a patient from 57-year-old, diagnosed with papillary serous carcinoma, Stage IIIC, who underwent surgery and was prescribed adjuvant chemotherapy in a context of optimal surgery, four cycles of paclitaxel and carboplatin.

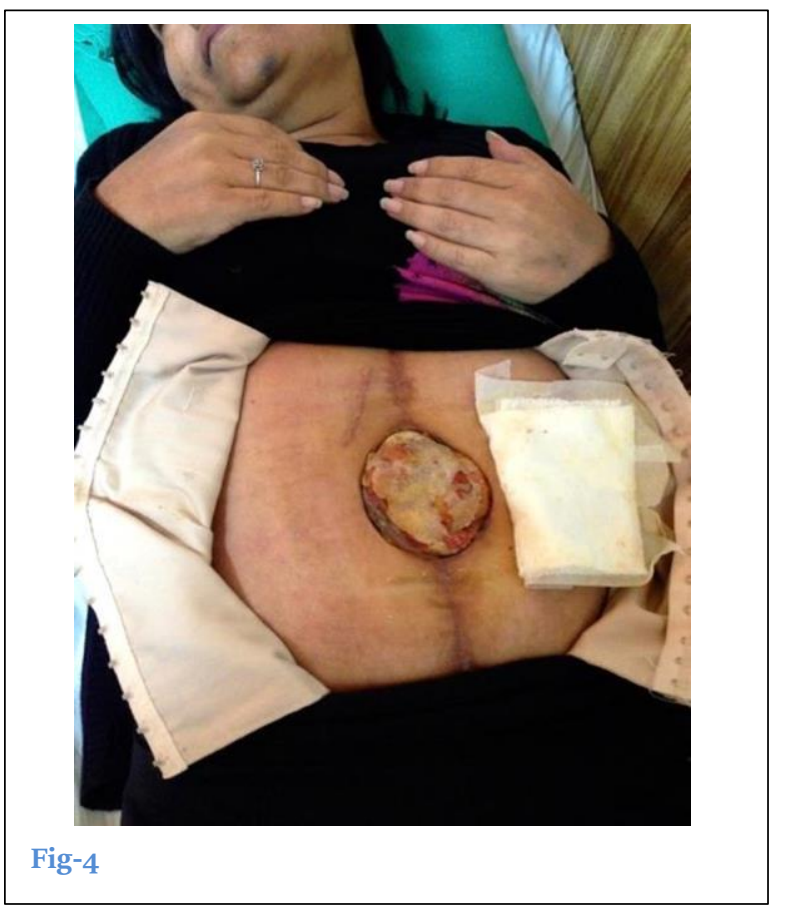

The surgery was performed in April 2014 and the systemic treatment concluded in October of the same year; 21 months after the end of the treatment and having remained in control and follow-up, erythematous lesions appeared in the navel and in the periumbilical skin area (Fig-4 and Fig-5).

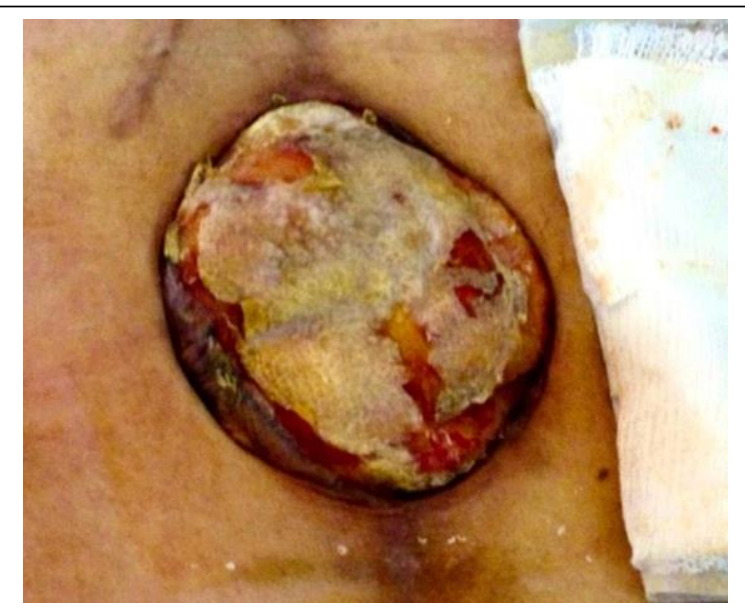

Fig-5

The skin biopsy showed metastasis of serous papillary carcinoma (Fig-6 and Fig-7).

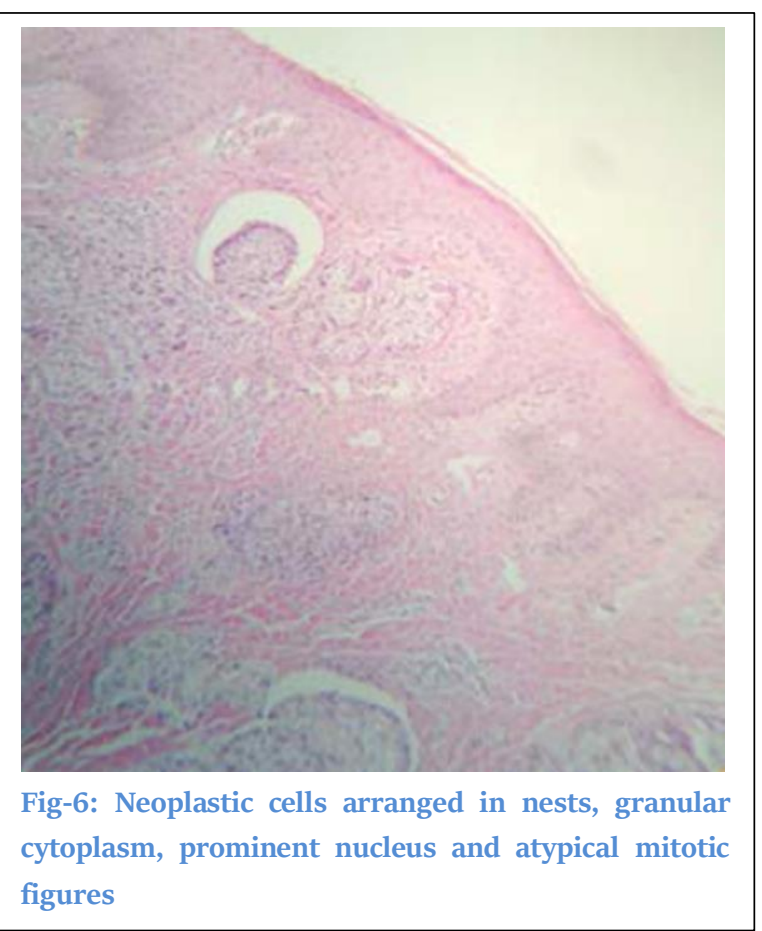

With the histopathological confirmation a 2nd line scheme was indicated, also based on platinum ("platinum-sensitive" disease) protocol in which we included bevacizumab [6,7]. Abdominal and pelvic CT showed a significant post-surgical umbilical hernia with increased omentum content (Fig-8 and Fig-9). 

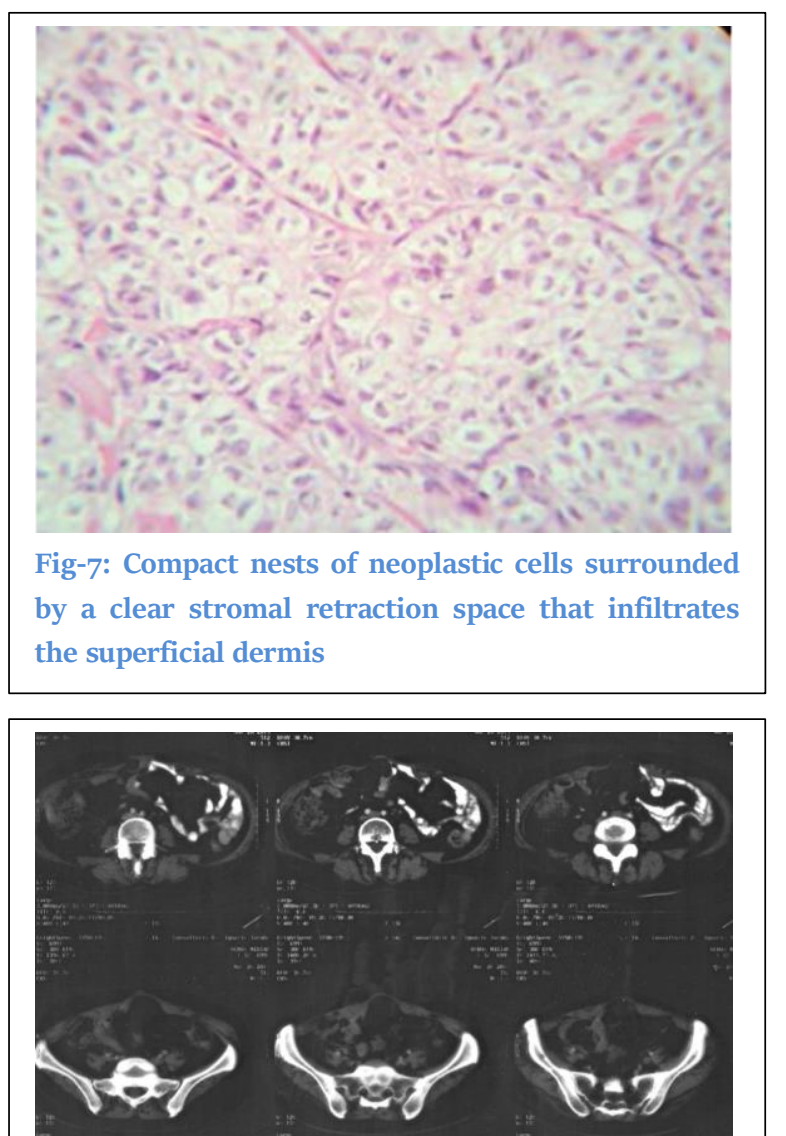

Fig-8

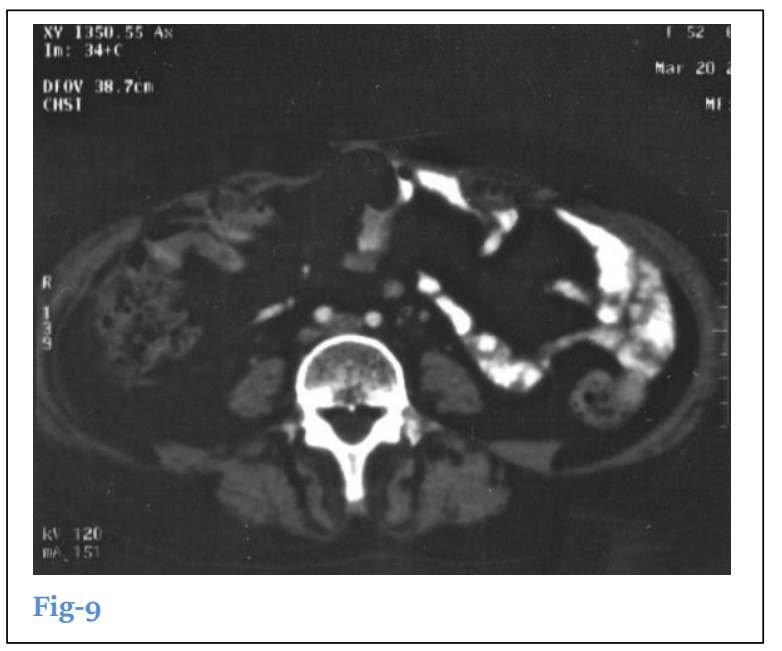

The patient, after three cycles of chemotherapy, made disease progression, no response at the skin level, poor general condition, sepsis, and death.

\section{Pathophysiology:}

The mechanism through which these tumors spreads to the umbilicus remains unclear, however, several hypotheses have been developed including three possible dissemination pathways: contiguity, lymphatic, and hematic spreading. The umbilicus is extensively connected to intraabdominal spaces due to several embryological remnants structures and holds a considerable amount of vascular anastomotic structures and peritoneal ligaments as a convergence point.

Despite $90 \%$ of the neoplastic lesions in the periumbilical area correspond to metastases; a not despicable $10 \%$ are primary malignancies of the local tissue being vitelline and uracus remnants adenocarcinomas the most frequent malignancies in this group .less than $1 \%$ of this nodule has benign nature like endometrium (Villars's nodule), epithelial cysts and fibrotic tissue $[8,9]$.

\section{Discussion}

Currently few doctors have seen this nodule in any of their patients, even among oncologists it is somewhat difficult to see, and the reason is none other than the earlier diagnosis of intra-abdominal cancer that prevents it from being so advanced as to cause metastasis in the periumbilical area. Among the cancers that can originate it, we find that in $52 \%$ are of digestive origin and in $28 \%$ of the gynecological cause being other locations less frequent. In most cases, it was not known that the patient was affected by cancer before this sign appeared, and only $40 \%$ of the cases are expressions of a recurrence of a previously known cancer.

The umbilicus is rarely the site of origin of a malignant tumor; however, when it is, the epidermoid type is the most frequent of the primary umbilical tumors [10]. The most common sites of origin of Mary Joseph nodule are the stomach and colon in men and the ovaries in women, as is our case. Other locations include the cecum, small intestine, bladder, uterine tube, cervix, prostate, endometrium, and pancreas. In our case, the original neoplasm of the metastatic lesion was ovarian adenocarcinoma. This places it within the group of abdominal tumors, the ovary is one of the neoplasms of this group that originated the nodule of Sister Mary Joseph [11]. Up to $40 \%$ of the cases are an expression of recurrent neoplasms; however, there are some cases of the initial presentation of skin involvement before the diagnosis of the primary 
neoplasm.

In most cases of Mary Joseph nodule, there are suggestive symptoms, while in $15 \%$ of cases it may be the first and only one [12]. Clinically it is a firm umbilical nodule, which may ulcerate or fissure, may have erythematous, brown or blue coloration, sometimes pruriginous, not painful on palpation. Patients often have gastrointestinal symptoms such as abdominal pain, weight loss, bloating, and nausea. The age of presentation in our patient was somewhat less than described since the average appearance is around 60 years of age $[13,14]$.

Other causes of an umbilical nodule of benign nature are fibroepithelial papilloma, dermatofibromas, malformations of the omphalomesenteric duct, hypertrophic scars, and umbilical hernias. Skin metastases from ovarian cancer are rare and, when they occur, are umbilical. There are reports of metastases in other locations such as the neck and scalp [15]. The CT scan usually shows a hyperdense tumor image that captures the contrast, or sometimes, a hernia sac is produced, with omentum content, as in our patient, besides being an excellent study for staging the disease.

The biopsy of the nodule is fundamental in the diagnosis of the origin of the tumor since the histological and immunohistochemical characteristics allow us to define the origin of the neoplasm $[16,17]$. The most frequent histological type is adenocarcinoma, as it happened with our patient. Likewise, the positive sample for $\mathrm{CK}_{7}$ (which can be positive in organs of glandular origin such as ovary, breast, pancreas, thyroid, etc.) and pan keratin (useful for epithelial neoplasms including those of gastrointestinal origin) allowed the diagnosis of a metastatic nodule of digestive carcinoma. In these cases, the CK2O marker is very useful, especially if we think of digestive tumors [18-20].

Differential diagnoses may include umbilical hernia, cutaneous endometriosis, pyogenic granuloma, keloid scar, melanoma, squamous cell carcinoma, among others. Some authors propose aggressive treatment combining surgical removal, chemotherapy, and radiotherapy; while other studies propose offering only palliative treatment because all patients are usually diagnosed in advanced stages of the disease [21]. In our patient the survival was very poor, dying three months after the diagnosis of the umbilical metastatic node.

The limitation of our work is due to the fact that it is a case report, being necessary to perform a greater number of observations or an epidemiological study to have more knowledge of this form of skin presentation in our literature; however, we consider its publication important because it is infrequent, as the only clinical manifestation of disease at a distance, since we could not document another metastatic site [22,23].

In conclusion, the presentation of an umbilical nodule with abdominal symptoms and a history of ovarian cancer makes it necessary to rule out not only recurrence of gynecological neoplasia, but also to rule out primary pathology of the umbilicus, the gastrointestinal tract, and other mainly intrabdominal organs, in order to make a timely diagnosis of a serious condition with serious impact on patient survival $[24,25]$.

\section{Funding}

This work has not been funded by any institution or organization.

\section{Conflict of Interest}

All authors have read and approved the final version of the manuscript. The authors have no conflicts of interest to declare.

\section{References}

[1] Miranda A, Alves M, Lopes F, Fonseca T. Nódulo de la hermana María José [Sister Mary Joseph' nodule]. Rev Clin Esp (Barc). 2014 May;214(4):e47. (Spanish) [PMID: 24513081]

[2] Miller T, Ashworth J, Richards S. Sister Mary Joseph nodule. BMJ. 2015 Oct 15;351:h5224. [PMID: 26472774]

[3] Espinel J, Pinedo E, Ojeda V, Guerra-del-Río M. Sister Mary Joseph's nodule. Rev Esp Enferm Dig. 2016 Feb;108(2):97. [PMID: 26838492] 
[4] Casimiro LM, Corell JV. Cutaneous metastases of internal neoplasm. Medicina Cutánea Ibero-LatinoAmericana. 2009;37(3):117-29.

[5] Urbano FL. Sister Joseph's nodule. Hospital Physician. 2001 May;37(5):33-44.

[6] Menzies S, Chotirmall SH, Wilson G, O'Riordan D. Sister Mary Joseph nodule. BMJ Case Rep. 2015 Jan 6;2015:bcr2014206808. [PMID: 25564635]

[7] Sánchez Y, Estrada G. The image in history: historical and pictorial review of the nodule of Sister María José in five cases. Annals Radiol Mexico. 2007;4:327-32.

[8] Davar S, Hanna D. Sister Mary Joseph's nodule. J Cutan Med Surg. 2012 May-Jun;16(3):201-204. [PMID: 22713446]

[9] Chirapongsathorn S, Kamath PS. Sister Mary Joseph's nodule. Mayo Clin Proc. 2015 Feb;9o(2):310. [PMID: 25659248]

[10] Rebaza Vásquez S. Cáncer de páncreas [Pancreas cancer]. Rev Gastroenterol Peru. 2016 AprJun;36(2):105-106. (Spanish) [PMID: 27409085]

[11] Kanji ZS, Gallinger S. Diagnosis and management of pancreatic cancer. CMAJ. 2013 Oct 1;185(14):121926. [PMID: 23610017]

[12] Seyfried TN, Huysentruyt LC. On the origin of cancer metastasis. Crit Rev Oncog. 2013;18(1-2):43-73. [PMID: 23237552]

[13] Bai XL, Zhang Q, Masood W, Masood N, Tang Y, Cao CH, Fu QH, Zhang Y, Gao SL, Liang TB. Sister Mary Joseph's nodule as a first sign of pancreatic cancer. World J Gastroenterol. 2012 Dec 7;18(45):6686-689. [PMID: 23236247]

[14] Vallejo Bernad C, Casamayor Franco MC, Hakim Alonso S. Sister Mary Joseph's nodule as initial pancreatic cancer manifestation. Rev Esp Enferm Dig. 2017 Feb;109(2):167-68. [PMID: 28006922]

[15] Sharma A, Sharma V. Image diagnosis: Sister Mary Joseph nodule. Perm J. 2014 Spring;18(2):e132. [PMID: 24867558]

[16] Akram M, Baig MA, Ali S. Sister Mary Joseph nodule, a forgotten nodule. J Ayub Med Coll Abbottabad. 2014 Jul-Sep;26(3):416-18. [PMID: 25671964]
[17] Shen Z, Yang X, Chen L, Hao F, Zhong B. Sister Mary Joseph's nodule as a diagnostic clue to metastatic colon carcinoma. J Clin Oncol. 2009 Jul 1;27(19):e1-2. [PMID: 19433679]

[18] Vagnonii M. Umbilical metastasis: Sister María José nodule. Arch Argent Dermatol. 2014;64(4):165-67. [19] Talebi S, Chaudhari S. Sister Mary Joseph nodule. QJM. 2016 Jun;109(6):419-20. [PMID: 26742569]

[20] Pereira WA, Humaire CR, Silva CS, Fernandes LH. Sister Mary Joseph's nodule: a sign of internal malignancy. An Bras Dermatol. 2011 Jul-Aug;86(4 Suppl 1):S118-20. [PMID: 22068789]

[21] Iavazzo C, Madhuri K, Essapen S, Akrivos N, Tailor A, Butler-Manuel S. Sister Mary Joseph's Nodule as a First Manifestation of Primary Peritoneal Cancer. Case Rep Obstet Gynecol. 2012;2012:467240. [PMID: 23133766]

[22] Ducreux M, Cuhna AS, Caramella C, Hollebecque A, Burtin P, Goéré D, Seufferlein T, Haustermans K, Van Laethem JL, Conroy T, Arnold D; ESMO Guidelines Committee. Cancer of the pancreas: ESMO Clinical Practice Guidelines for diagnosis, treatment and follow-up. Ann Oncol. 2015 Sep;26 Suppl 5:v56-68. [PMID: 26314780]

[23] Bdeiri K, Kamar FG. Cutaneous metastasis of pancreatic adenocarcinoma as a first clinical manifestation: a case report and review of the literature. Gastrointest Cancer Res. 2013 Mar;6(2):613. [PMID: 23745161]

[24] Giner Galvañ V. Nódulo de la Hermana María (José). Significado y manejo clínico [Sister Mary Joseph's nodule. Its clinical significance and management]. An Med Interna. 1999 Jul;16(7):365-70. (Spanish) [PMID: 10481340]

[25] Rodríguez JM, Sanz Peláez O, Santana L, Rey A, Suárez Ortega S, Betancor León P. Nódulo de la hermana María José como manifestación de cáncer de origen desconocido: presentación de un caso [The Sister Joseph's nodule-like manifestation of carcinoma of unknown origin: presentation of one case]. An Med Interna. 2005 Jun;22(6):285-87. (Spanish) [PMID: 16011409]

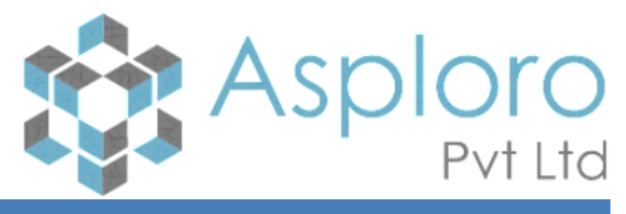

